\title{
Species-specific biomass drives macroalgal benthic primary production on temperate rocky reefs
}

\author{
Michael Spector ${ }^{\mathrm{a}, *}$ and Matthew S. Edwards \\ Department of Biology, San Diego State University, 5500 Campanile Dr., San Diego, CA 92182, USA
}

Temperate rocky reefs dominated by the giant kelp, Macrocystis pyrifera, support diverse assemblages of benthic macroalgae that provide a suite of ecosystem services, including high rates of primary production in aquatic ecosystems. These forests and the benthic macroalgae that inhabit them are facing both short-term losses and long-term declines throughout much of their range in the eastern Pacific Ocean. Here, we quantified patterns of benthic macroalgal biomass and irradiance on rocky reefs that had intact kelp forests and nearby reefs where the benthic macroalgae had been lost due to deforestation at three sites along the California, USA and Baja California, MEX coasts during the springs and summers of 2017 and 2018. We then modeled how the loss of macroalgae from these reefs impacted net benthic productivity using species-specific, mass-dependent rates of photosynthesis and respiration that we measured in the laboratory. Our results show that the macroalgal assemblages at these sites were dominated by a few species of stipitate kelps and fleshy red algae whose relative abundances were spatially and temporally variable, and which exhibited variable rates of photosynthesis and respiration. Together, our model estimates that the dominant macroalgae on these reefs contribute 15 to $4,300 \mathrm{mg} \mathrm{C} \mathrm{m}^{-2} \mathrm{~d}^{-1}$ to net benthic primary production, and that this is driven primarily by a few dominant taxa that have large biomasses and high rates of photosynthesis and / or respiration. Consequently, we propose that the loss of these macroalgae results in the loss of an important contribution to primary production and overall ecosystem function.

Key Words: benthic production; ecosystem function; kelp forest; macroalgae; primary production

\section{INTRODUCTION}

Many species of macroalgae serve as foundation species throughout temperate and subpolar nearshore rocky reef ecosystems where they provide a multitude of ecosystem services (Schiel and Foster 2015, Ware et al. 2019, Edwards et al. 2020). Kelps (large brown algae in the Order Laminariales), in particular, create subtidal forests that alter hydrodynamic, chemical, and light conditions (Jackson 1984, 1997, Clark et al. 2004, Wernberg et al. 2005, Hondolero and Edwards 2017, Pfister et al. 2019), provide food and nursery habitat for commer cially and recreationally important fishery species (Holbrook et al.
1990, Carr 1994), enhance primary production and carbon export to adjacent ecosystems (Bradley and Bradley 1993, Hobday 2000, Reed and Brzezinski 2009, Reed et al. 2011, Miller et al. 2015), and generally support high species diversity (Dayton et al. 1984, Wernberg et al. 2005, Siddon et al. 2008, Konar et al. 2017, Metzger et al. 2019). Further, given their high rates of primary production, kelp forests act as localized buffers against ocean acidification by elevating seawater $\mathrm{pH}$ as they take up inorganic carbon, and reducing episodes of anoxia by releasing dissolved oxygen (DO) during photosynthesis (Frieder et
(9) $\$$ This is an Open Access article distributed under the terms of the Creative Commons Attribution Non-Commercial License (http://creativecommons.org/licenses/by-nc/3.0/) which permits unrestricted non-commercial use, distribution, and reproduction in any medium, provided the original work is properly cited.
Received Jun 28, 2020, Accepted August 19, 2020

* Corresponding Author

E-mail: mspector.ecology@gmail.com

Tel: +1-310-880-9311

${ }^{\text {a }}$ Present address: NOAA Channel Islands National Marine Sanctuary University of California Santa Barbara Ocean Science Education Building 514, MC 6155 Santa Barbara, CA 93106-6155, USA 
al. 2012, Klinger et al. 2017, Murie and Bourdeau 2020). However, in recent decades, kelp forests have undergone temporary losses (Edwards and Hernandez-Carmona 2005, Hondolero and Edwards 2017) and long-term declines (Estes et al. 1998, Vásquez et al. 2006, Connell and Russell 2010, Wernberg et al. 2010, Krumhansl et al. 2016) in many regions of the world due to a variety of environmental stressors. This has resulted in the loss of many of the ecosystem services they provide, especially primary productivity and carbon storage (Reed et al. 2011, Wilmers et al. 2012, Edwards et al. 2020).

Estimating primary production by individual benthic macroalgae and whole-assemblages in coastal zones has been done using a variety of laboratory and field-based techniques (e.g., Smith and Hollibaugh 1993, Duarte and Cebrián 1996, Reed et al. 2008, Barrón and Duarte 2015). For example, net primary production and respiration by individual macroalgae can be quantified in the laboratory by measuring changes in seawater $\mathrm{DO}$ within controlled incubations conducted under different irradiances (Shipe and Brezinski 2003, Brown et al. 2014, Kim et al. 2016). In the field, benthic chambers equipped with DO sensors can be sealed over individual macroalgae to measure in situ rates of photosynthesis under different light intensities and at different depths (Rodgers et al. 2015). Similarly, open-bottom chambers can be sealed to the benthos over whole macroalgal assemblages to estimate net community production (NCP) and gross primary production (GPP) during the day and community respiration (CR) during the night by measuring changes in DO within the chambers (Miller et al. 2011, Olivé et al. 2016, Edwards et al. 2020). Productivity values can then be compared to measurements of light use relationships by individual species done in the laboratory, which can be scaled by their biomass and light levels measured in the ecosystem to estimate NCP, GPP, and CR (Middleboe et al. 2006, Miller et al. 2011). In general, GPP by the autotrophs can be determined as the difference between NCP and CR, and the balance between GPP and CR can be a direct measure of ecosystem function and overall ecosystem productivity (Duarte and Agustí 1998, Williams 1998).

Macrocystis pyrifera (hereafter Macrocystis) is the largest and most widespread kelp species along the west coast of North America (Schiel and Foster 2015), and the forests it creates are characterized as having some of the highest rates of primary production observed in marine ecosystems (Reed and Brzezinski 2009). Macrocystis forests support diverse assemblages of benthic macroalgae, including sub-canopy and understory brown, red and green algae, all of which contribute to primary production in the coastal zone (Dayton et al. 1984, Reed and Foster 1984, Clark et al. 2004, Miller et al. 2011). However, the relative importance of each species to this production undoubtedly varies across spatial and temporal scales coincident with their abundances, metabolisms, and incipient environmental conditions. Thus, understanding how different species contribute to primary production is necessary to fully understanding overall productivity in these ecosystems (Middleboe et al. 2006, García-Robledo and Corzo 2011, Miller et al. 2011). Macrocystis forests also support a wide range of fishes, invertebrates, and microbes (Bodkin 1988, Holbrook et al. 1990, Carr 1994, Schiel and Foster 2015, Minich et al. 2018), which together with the algae drive CR. However, these forests have undergone short-term (months to years) losses at several sites due to large storms (e.g., Dayton et al. 1984, 1998, Ebeling et al. 1985, Seymour et al. 1989), and widespread, long-term (years to decades) declines in abundance and poleward shifts in their range limits during ENSO events (Edwards 2004, Edwards and Hernandez-Carmona 2005, Edwards and Estes 2006, Wernberg et al. 2010). These losses negatively affect associated species and their fisheries (e.g., Bodkin 1988, Graham 2004), and may negatively affect patterns of primary productivity as seen in Eularia fistulos $a$ beds along the Aleutian Archipelago (Edwards et al. 2020). Indeed, recent investigations that have examined rates of primary production in the nearshore have found that algal biomass is the most important driver of productivity within coastal kelp forests (Reed et al. 2008, Miller et al. 2011, Schuurmans et al. 2015), but this may vary among geographic sites and seasons with different macroalgal assemblages and ocean conditions. Here, we modeled how the loss of understory fleshy macroalgae from subtidal reefs affects net benthic production (NBP) and benthic respiration (BR) at three sites along the California, USA and Baja California, MEX coasts. Similar to Miller et al. (2012), we used species-specific light use relationships measured in the laboratory, and in situ measurements of each species' biomass and irradiance measured in the field at each site in our model. Due to logistic constraints, we considered only the large and conspicuous benthic species that made up $>80 \%$ of the total macroalgal biomass on the rocky reefs within our study sites (e.g., see Dayton et al. 1984, Edwards 2004). Unfortunately, we were unable to include crustose coralline algae or microalgae in our model, which may provide compensatory production (e.g., Miller et al. 2012). Our overarching goal was to model the contribution of these fleshy macroalgae to overall benthic productivity, and to 


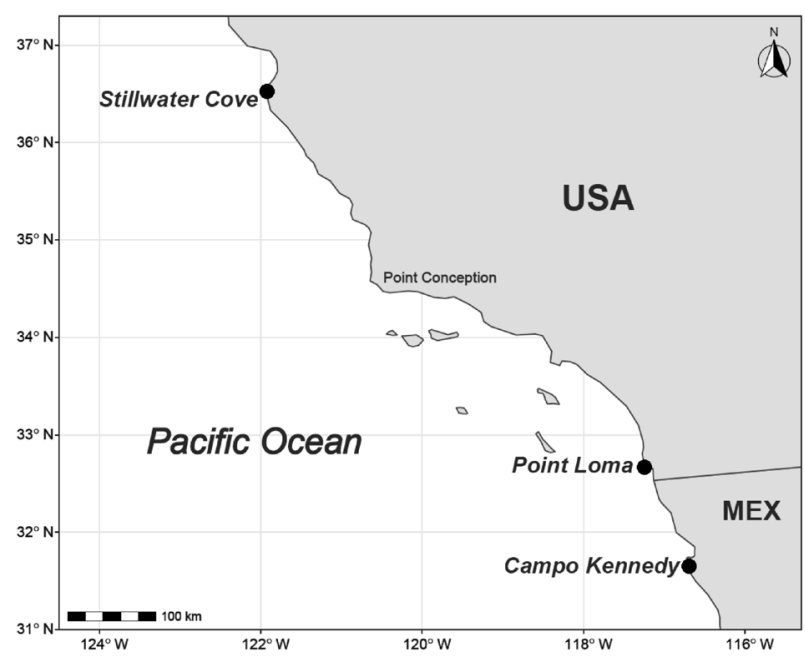

Fig. 1. Map of study sites along the coast of California, USA to Baja California, MEX. From north to south: Stillwater Cove, Carmel Bay, California; Point Loma, San Diego, California; Campo Kennedy, Ensenada, Mexico. All sites occur within the native range of Macrocystis pyrifera and contain two habitat types, forested and deforested.

estimate how their loss due to deforestation affects productivity on these reefs.

\section{MATERIALS AND METHODS}

\section{Study sites}

This study took place at three biogeographically distinct sites in California, USA and Baja California, MEX during 2017 and 2018. Specifically, these sites were Stillwater Cove, in Carmel Bay, California, USA (36 $33^{\circ} 42.2^{\prime \prime}$ N, 121 $\left.{ }^{\circ} 56^{\prime} 37.6^{\prime \prime} \mathrm{W}\right)$, Point Loma, near San Diego, California $\left(32^{\circ} 41^{\prime} 24.0^{\prime \prime} \mathrm{N}, 117^{\circ} 15^{\prime} 36.0^{\prime \prime} \mathrm{W}\right)$, and Campo Kennedy, on the south side of Punta Banda near Bahía Todos Santos, México ( $\left.31^{\circ} 41^{\prime} 57.3^{\prime \prime} \mathrm{N}, 116^{\circ} 40^{\prime} 55.8^{\prime \prime} \mathrm{W}\right)$; hereafter Stillwater Cove, Point Loma, and Campo Kennedy, respectively (Fig. 1). These sites experience different sea surface temperatures, wave exposures, and nutrient availabilities, and are characterized by different benthic algal assemblages (Edwards 2001, Edwards and Estes 2006, Bell et al. 2015). Further, some macroalgae may exhibit adaptation to local oceanographic conditions in the different geographic sites and thus demonstrate different rates of productivity, even under similar ocean conditions (e.g., Kopczak et al. 1991). At each site, a 10-15 m deep rocky reef that was dominated by a Macrocystis forest and a nearby reef that was historically dominated by Macrocystis but became deforested were identified based on historic data sets (e.g., Edwards and Estes 2006), local collaborator knowledge, and diver surveys (M. Spector personal observation). The reef pairs at each site were separated by less than $500 \mathrm{~m}$ and had similar depths (10$15 \mathrm{~m}$ ), substrate types, and swell exposures. The mechanisms of deforestation were not explored in this study; however, grazing (mainly by sea urchins) appeared to be the primary cause of deforestation at Stillwater Cove and Campo Kennedy, while a combination of urchin grazing and ocean waves appeared to be the primary cause of deforestation at Point Loma.

Stillwater Cove has been host to numerous kelp forest studies over the last several decades (e.g., Reed and Foster 1984, Edwards 1998, Clark et al. 2004). The site is characterized as having infrequent, strong, storm-driven waves and cold nutrient-rich seawater (Edwards and Estes 2006, Reed et al. 2008). The granite rocky reefs have shifted between kelp-dominated and urchin-dominated (i.e., deforested) since at least 2014 (M. Carr personal communication). The deforested habitat was characterized by an urchin barren composed of numerous Strongylocentrotus purpuratus and a few Mesocentrotus fransicanus but was otherwise devoid of macroalgae for the duration of this study. In contrast, the forested habitat was located $200 \mathrm{~m}$ to the southeast and dominated by dense stands of large ( $>30$ stipes) Macrocystis individuals, a sub-canopy of Pterygophora californica and numerous species of understory red algae for the duration of this study.

Point Loma, like Stillwater Cove, has been host to numerous studies and experimental manipulations over the past several decades (e.g., Dayton et al. 1984, Frieder et al. 2012, Carney et al. 2013, VanMeter and Edwards 2013). This site experiences warmer temperatures, reduced nutrient levels, and weaker, less frequent storms compared to Stillwater Cove (Edwards 2004, Reed et al. 2008, Bell et al. 2015). Point Loma's substrate is characterized by a flat, sandstone bottom with low rugosity. The forested and deforested habitats were separated by $\sim 20$ $\mathrm{m}$, and were located near the southern end of the Point Loma peninsula. The deforested habitat had a sparse mix of fleshy and coralline red algae, but was otherwise devoid of large macroalgae, while the forested habitat had many mid-sized (10-15 stipes) Macrocystis individuals, a dense sub-canopy of P. californica, Laminaria farlowii, and Eklonia arborea, and an understory composed of numerous species of red and brown algae.

Located just south of Ensenada, MEX, Campo Kennedy experiences strong upwelling and typically cooler sea surface temperatures than Point Loma (Edwards and 
Estes 2006, Edwards 2019). The substrate is composed of rocky cobble and large, flat granitic plateaus. Like Stillwater Cove, this deforested area was dominated by numerous S. purpuratus and a few M. fransicanus and was devoid of macroalgae for the duration of this study. The forested habitat was located approximately $500 \mathrm{~m}$ to the north and was dominated by numerous small (1-5 stipes) Macrocystis, a sub-canopy of P. californica and E. arborea, and a diverse assemblage of understory brown and red algae.

\section{Estimates of algal diversity and biomass}

The benthic macroalgal communities were characterized within each habitat (forested and deforested) at each site in the spring and summer 2018, while Point Loma and Campo Kennedy were also surveyed in summer 2017. In addition, Point Loma was also surveyed in winter 2018, and Campo Kennedy was surveyed in spring 2017. These differences in additional sampling dates were due to logistic constraints associated with access to these sites and winter storms that precluded sampling. Therefore, only the two sampling dates when all three sites were surveyed (i.e., spring and summer 2018) were used to compare productivity among the three sites in our model, but we present our model results for the additional sampling times. During each survey, a $30 \mathrm{~m}$ main transect was initiated from a randomly selected location at each site and run parallel to shore. From this main transect line, three $20 \mathrm{~m} \times 2 \mathrm{~m}$ transects (i.e., $\mathrm{n}=3$, total sample area $=120$ $\mathrm{m}^{2}$ per site) were run along random compass headings in a 'bicycle spoke' design, and divers collected all fleshy macroalgae occurring within three $0.25 \mathrm{~m}^{2}$ quadrats that were placed at randomly selected positions along each of the $20 \mathrm{~m}$ transects (i.e., $\mathrm{n}=9$ total quadrats per each habitat type $\times$ site $\times$ date combination). All macroalgae were placed in mesh bags and immediately taken to San Diego State University's Coastal and Marine Institute Laboratory (CMIL) in dark coolers filled with seawater where they were identified to the lowest taxonomic level, enumerated, and weighed. The cooler was placed in a temperature-controlled room and aerated until the samples could be measured for photosynthesis and respiration (approximately $24 \mathrm{~h}$ ). Each alga was visually inspected to qualitatively asses its condition before being used for further experimentation. The quantification of algal wet weight (biomass) collected from the field was used to identify the dominant species (i.e., those when combined, comprised at least $80 \%$ of the total algal biomass) present in each habitat, and to later scale mass-specific laboratory estimates of productivity to the field.

Differences in understory algal assemblages within the forested habitats were assessed among the study sites and sample dates with a two-way permutation analysis of variance (PERMANOVA) based on Bray-Curtis similarities using Primer-E Ltd. (ver. 7) (Anderson 2017). Prior to testing, data were fourth root transformed to reduce the influence of overly abundant species, and a non-metric multidimensional scaling plot was used to visualize differences in overall community assemblages among sites. This revealed that the sites exhibited different temporal variation in algal assemblages (see Results), which led us to examine differences among sampling dates within each site separately. To do this, separate one-way PERMANOVAs were used to assess differences in the algal assemblages among sampling dates at each site, and Similarity Percentage analyses (SIMPERs) were used to estimate how each of the algal species contributed to the observed similarities within each site.

\section{Laboratory-based estimates of productivity}

To measure rates of photosynthesis and respiration in the dominant benthic macroalgae at each site under a range of irradiances that these algae naturally experienced at their respective sites, three replicate preweighed samples $(n=3)$ were placed individually in a $500 \mathrm{~mL}$ glass biological oxygen demand (BOD) bottle that was filled with filtered seawater. The BOD bottle was equipped with a recirculating water jacket that was set to hold the seawater at the same temperature at which the samples were collected from the field $\left(9-17^{\circ} \mathrm{C}\right.$ depending on site and date). The BOD bottle was placed on a magnetic stirring plate and a small rubber-coated metal stirring bar was added to the bottle to keep water circulating and prevent boundary layer formation around the algal tissue. The bottle was rinsed with filtered seawater between samples. Due to differences in algal morphologies, we could not standardize tissue weight and thallus areas across all species, but these were kept consistent for all replicates within each species (5-15 g depending on species). Further, only non-fouled algae with intact thalli were used for photosynthesis measurements. For algae with stoloniferous morphologies like Botryocladia pseudodichotoma, a single branch with multiple vesicular enlargements was clipped and kept to $\sim 15 \mathrm{~g}$. For large, stipitate kelps such as Laminaria farlowii and Pterygophora californica, a $\sim 10 \mathrm{~g}$ section was excised from the middle of the vegetative blade. For small foliose algae like Zonaria farlowii, whole individuals weighing $\sim 7 \mathrm{~g}$ were used. 
For all photosynthetic measurements, care was taken to reduce self-shading by the macroalgae by carefully positioning their thalli in the BOD bottle. We do not believe supersaturation took place during the measurements given the selected light levels and short duration of the incubations (J. H. Kim personal communication).

Approximately $1 \mathrm{~h}$ before they were measured, the algal tissues were taken from the cooler and placed in fresh filtered seawater and left in the dark. Three replicate measurements of irradiance-dependent photosynthesis were made for each species by exposing the tissues to eight increasing irradiances for ten minutes per irradiance and measuring changes in DO within the bottle using an YSI OBOD self-stirring optical probe (YSI Inc., Yellow Springs, $\mathrm{OH}$, USA). However, unlike traditional P-E curves, which extend irradiance well above saturating irradiances, we focused a larger number of measurements within a narrower range of irradiances that represent levels the algae typically experience in these kelp forests in order to better parametrize our model, especially at the lower irradiances. These irradiances were determined using Odyssey PAR loggers (Dataflow Systems Ltd., Christchurch, New Zealand) that were calibrated per the manufacture's recommendation. Here, the loggers were placed in a 5-gallon bucket filled with seawater and left in the full sun for one hour. The data were downloaded and compared to a reference logger and corrected using proprietary software and tables provided by the manufacturer (Odyssey). Following calibration, three Odyssey PAR loggers were placed on the benthos at $7 \mathrm{~m}$ intervals along the main transect used for the diver surveys for algal biomass within each habitat at each site during spring and summer 2018. The loggers were attached to holders made from PVC and secured to cinderblocks to maintain their position $0.25 \mathrm{~m}$ above the benthos for $48 \mathrm{~h}$ during each deployment. This revealed that $>99 \%$ of all irradiances measured within these kelp beds ranged between 0 and $120 \mu \mathrm{mol}$ photons $\mathrm{m}^{-2} \mathrm{~s}^{-1}$. Indeed, irradiances exceeded $120 \mu \mathrm{mol}$ photon $\mathrm{m}^{-2} \mathrm{~s}^{-1}$ only once, during a three-hour period in Point Loma during summer 2018, which accounted for less than $1 \%$ of all measurements at this site. In contrast, when considered across all sites and dates, $\sim 71 \%$ of all daytime irradiances occurred between 0 and $10 \mu \mathrm{mol}$ photons $\mathrm{m}^{-2} \mathrm{~s}^{-1}, \sim 22 \%$ of the irradiances occurred between 10 and $30 \mu \mathrm{mol}$ photons $\mathrm{m}^{-2} \mathrm{~s}^{-1}, \sim 4 \%$ of the irradiances occurred between 30 and $60 \mu \mathrm{mol}$ photons $\mathrm{m}^{-2}$ $\mathrm{s}^{-1}$, and $\sim 3 \%$ of the irradiances occurred between 60 and $120 \mu \mathrm{mol}$ photons $\mathrm{m}^{-2} \mathrm{~s}^{-1}$. Consequently, we used 2, 3, 8, $30,40,62$, and $116 \mu \mathrm{mol}$ photon $\mathrm{m}^{-2} \mathrm{~s}^{-1}$ for our irradiancedependent photosynthesis measurements, plus $0 \mu \mathrm{mol}$ photon $\mathrm{m}^{-2} \mathrm{~s}^{-1}$ (i.e., darkness) to estimate respiration.

To quantify the relationships between photosynthesis and the observed irradiances at our study sites, and ultimately model how much production was contributed by each species, we used R: The R Project for Statistical Computing (2019) to identify a power function that best fit the irradiance-dependent photosynthesis curves for oxygen evolution per gram of algae per minute for different irradiance levels (Eq. 1).

$$
\mathrm{y}=\mathrm{A} \times(\mathrm{x})^{\mathrm{B}}
$$

, where A and B represent the y-intercept and the slope, respectively, and $\mathrm{x}$ is irradiance.

This provided an estimate of the amount of oxygen produced via photosynthesis or consumed via respiration for each species per gram of thallus, per hour for each of the eight irradiance levels. We then scaled these estimates to each species' biomass observed within each sites during each sample time, as estimated from the diver surveys, and combined these with hourly in situ measurements of irradiance over the diurnal cycle to model the amount of primary production and respiration each species contributes (e.g., Middleboe et al. 2006, Miller et al. 2011). Finally, we summed these estimates across the dominant species within the kelp forests at each site to model the total amount of production/respiration that these benthic algae contribute to NBP and BR.

\section{RESULTS}

\section{Estimates of algal diversity and biomass}

Although a few understory macroalgae were observed in low abundances within the deforested area at Point Loma, our diver surveys verified they were completely absent from the deforested areas in Stillwater Cove and Campo Kennedy during all sampling periods. In contrast, understory macroalgae were consistently present, often in in high abundances, in each of the kelp forests (Table 1, Fig. 2), although their species compositions and biomasses varied significantly among the three study sites (PERMANOVA, pseudo- $\mathrm{F}_{4,16}=3.233, \mathrm{p}<0.001$ ) and sampling dates (pseudo- $\left.\mathrm{F}_{2,16}=15.361, \mathrm{p}<0.001\right)$ (Table 2, Fig. 3). In general, Point Loma and Stillwater Cove had similarly high biomasses of benthic macroalgae, while Campo Kennedy had relatively low biomass of macroalgae, but this varied among the sampling periods (Fig. 2). Further, the species compositions also varied among the sample periods differently in each of the study sites (Site 
$\times$ Date interaction: pseudo- $\left.\mathrm{F}_{3,16}=2.302, \mathrm{p}=0.017\right)$. Consequently, for the remainder of this paper we consider temporal patterns of macroalgal diversity and biomass within each site separately.

\section{Laboratory-based estimates of benthic produc- tivity}

We modeled the contribution of the dominant benthic macroalgae to NBP and BR by fitting laboratory-based oxygen production and / or consumption values to hourly estimates of in situ irradiances that were integrated over complete diurnal cycles, and then scaling these to each species' estimated biomass at that site during each sampling period. Our model suggests that both NBP and $\mathrm{BR}$ varied among the three sites and two sampling periods (Table 3, Fig. 4). Specifically, during spring 2018, NBP was greatest at Stillwater Cove, intermediate at Campo

Table 1. Biomass (wet weight, g) of all benthic macroalgae observed in the kelp forests at Stillwater Cove, Point Loma, and Campo Kennedy during the diver surveys on each sampling date in 2017 and 2018

\begin{tabular}{|c|c|c|c|c|c|c|c|c|c|c|}
\hline \multirow[b]{2}{*}{ Species } & \multicolumn{2}{|c|}{ Stillwater Cove } & \multicolumn{4}{|c|}{ Point Loma } & \multicolumn{4}{|c|}{ Campo Kennedy } \\
\hline & Spring & $\begin{array}{c}\text { Summer } \\
2018\end{array}$ & $\begin{array}{c}\text { Summer } \\
2017\end{array}$ & $\begin{array}{l}\text { Winter } \\
2018\end{array}$ & $\begin{array}{l}\text { Spring } \\
2018\end{array}$ & $\begin{array}{c}\text { Summer } \\
2018\end{array}$ & $\underset{2017}{\text { Spring }}$ & $\begin{array}{l}\text { Summer } \\
2017\end{array}$ & $\begin{array}{c}\text { Spring } \\
2018\end{array}$ & $\begin{array}{c}\text { Summer } \\
2018\end{array}$ \\
\hline SDI (H) & 0.936983 & 1.041283 & 2.120498 & 1.591063 & 1.424942 & 0.892504 & 1.471965 & 2.024197 & 1.104628 & 0.884581 \\
\hline Acrosorium spp. & 0 & 0 & 0 & 0 & 0 & 0 & 36 & 0 & 0 & 0 \\
\hline $\begin{array}{l}\text { Botryocladia } \\
\text { pseudodichotoma }\end{array}$ & 0 & 0 & 114 & 273 & 95 & 0 & 127 & 0 & 43 & 10 \\
\hline $\begin{array}{l}\text { Chondracanthus } \\
\text { canaliculatus }\end{array}$ & 0 & 0 & 50 & 0 & 0 & 0 & 64 & 0 & 0 & 0 \\
\hline $\begin{array}{l}\text { Callophyllis } \\
\text { flabellulata }\end{array}$ & 0 & 0 & 0 & 0 & 0 & 0 & 0 & 50 & 0 & 0 \\
\hline $\begin{array}{l}\text { Cryptopleura } \\
\text { ruprechtiana }\end{array}$ & 0 & 350 & 50 & 25 & 5 & 30 & 0 & 50 & 5 & 5 \\
\hline Calliarthron spp. & 0 & 0 & 479 & 0 & 0 & 75 & 164 & 275 & 0 & 0 \\
\hline Corallina spp. & 0 & 0 & 50 & 14 & 0 & 0 & 0 & 0 & 0 & 0 \\
\hline $\begin{array}{c}\text { Dictyoneurum } \\
\text { californicum }\end{array}$ & 730 & 700 & 0 & 0 & 0 & 0 & 0 & 0 & 0 & 0 \\
\hline Ecklonia arborea & 0 & 0 & 1,530 & 0 & 0 & 35 & 0 & 0 & 0 & 0 \\
\hline Gelidium spp. & 0 & 0 & 220 & 5 & 25 & 0 & 0 & 350 & 480 & 220 \\
\hline $\begin{array}{l}\text { Leptoclodia } \\
\text { binghamiae }\end{array}$ & 0 & 0 & 555 & 23 & 75 & 785 & 0 & 0 & 0 & 0 \\
\hline Laminaria farlowii & 0 & 0 & 1,450 & 700 & 1,370 & 2,715 & 0 & 0 & 0 & 0 \\
\hline $\begin{array}{l}\text { Laminaria spp. } \\
\text { (juvenile) }\end{array}$ & 0 & 0 & 50 & 14 & 10 & 0 & 0 & 190 & 0 & 0 \\
\hline $\begin{array}{l}\text { Pterygophora } \\
\text { californica }\end{array}$ & 1,910 & 1,570 & 712 & 525 & 235 & 40 & 0 & 0 & 0 & 0 \\
\hline Prionitis linearis & 0 & 0 & 404 & 196 & 715 & 0 & 1,353 & 300 & 0 & 300 \\
\hline $\begin{array}{l}\text { Rhodymenia } \\
\text { californica }\end{array}$ & 0 & 0 & 50 & 0 & 0 & 20 & 0 & 0 & 0 & 0 \\
\hline Sargassum horneri & 0 & 0 & 0 & 0 & 0 & 0 & 50 & 150 & 65 & 0 \\
\hline $\begin{array}{l}\text { Stephanocystis } \\
\text { osmundacea }\end{array}$ & 510 & 75 & 756 & 91 & 295 & 95 & 95 & 350 & 20 & 0 \\
\hline Zonaria farlowii & 0 & 0 & 0 & 0 & 0 & 0 & 118 & 450 & 5 & 10 \\
\hline
\end{tabular}

Macroalgae were collected from within nine randomly placed $0.5 \mathrm{~m}^{2}$ quadrats within each site on each sampling date. The dominant macroalgae (i.e., those whose combined biomass comprised $>80 \%$ of the total algal biomass at each site) were used to compare modeled productivity among the sites. Differences in sampling frequency were due to logistical constraints.

SDI, Shannon Diversity Index.

Table 2. PERMANOVA testing differences in understory macroalgal assemblages among studying sites and sampling dates

\begin{tabular}{lrccccc}
\hline Source & df & SS & MS & Pseudo-F & P $($ perm $)$ & $\omega^{2}$ \\
\hline Date & 4 & 12,784 & $3,196.1$ & 3.2331 & 0.001 & 11.6 \\
Site & 2 & 30,371 & 15,185 & 15.361 & 0.001 & 53.3 \\
Date $\times$ Site & 3 & $6,826.9$ & $2,275.6$ & 2.302 & 0.017 & 11.9 \\
Error & 16 & 15,817 & 988.6 & - & - & 23.2 \\
\hline
\end{tabular}

Site and date were considered fixed factors. Prior to analysis, data were fourth root transformed to down weigh the influence of overly abundant species. $\omega^{2}$ denotes the amount of variation (\% of total) that was attributed to each factor (Graham and Edwards 2001). 
Stillwater Cove

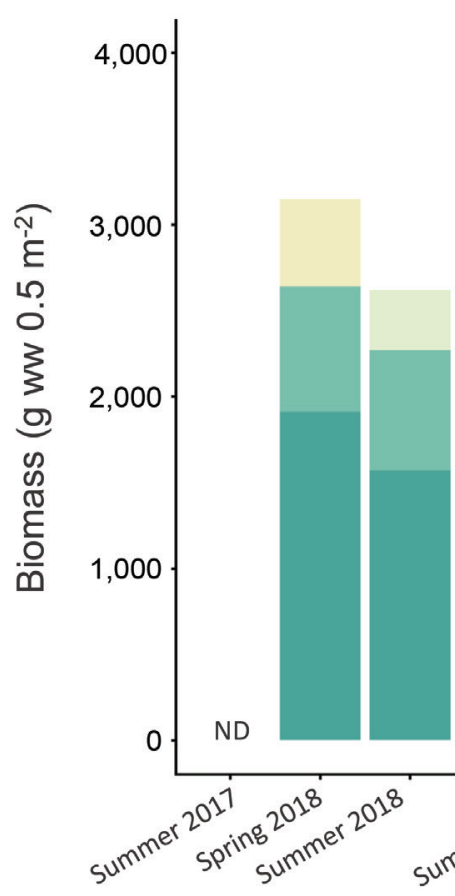

Point Loma

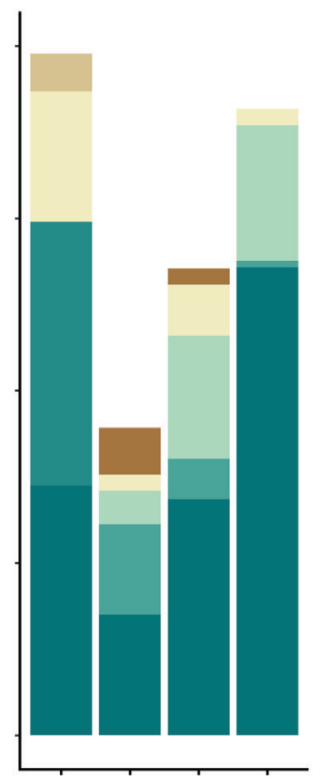

$20172018 \times 2018$

\section{Campo Kennedy}

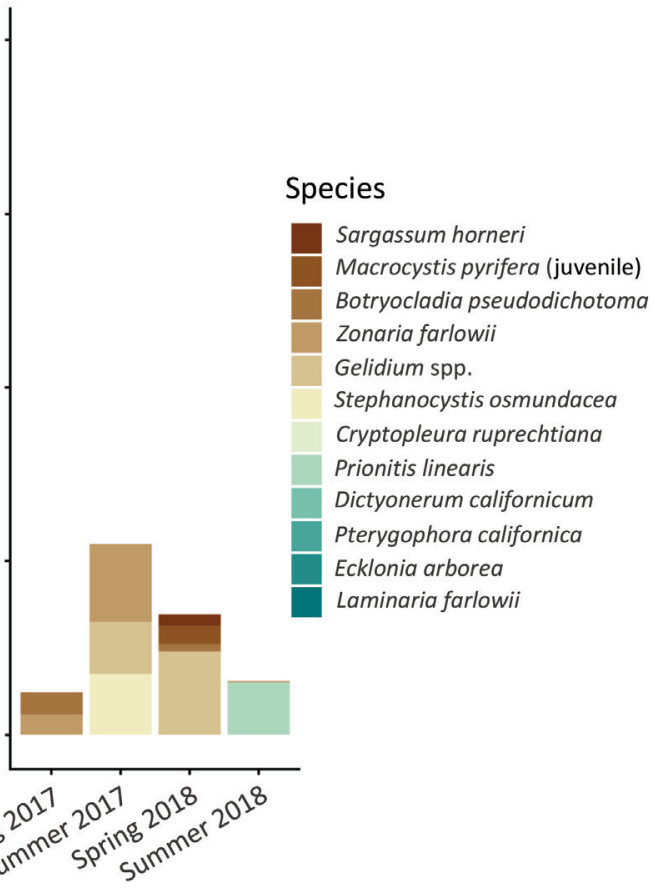

\section{Sampling date}

Fig. 2. Biomass (wet weight) of the dominant benthic macroalgae (i.e., those that made up $>80 \%$ of the total algal biomass) observed in each study site during each sampling event. These species were used to generate species-specific rates of productivity from all sampling dates in 2017 and 2018. The macroalgae were collected from within nine randomly placed $0.5 \mathrm{~m}^{2}$ quadrats along the three $20 \mathrm{~m}^{2}$ transects at each site. Data from spring and summer 2018 were used to compare modeled productivity among the study sites. Differences in sampling frequency were due to logistical constraints, ND indicates no data. [Colour figure can be viewed at http://www.e-algae.org].

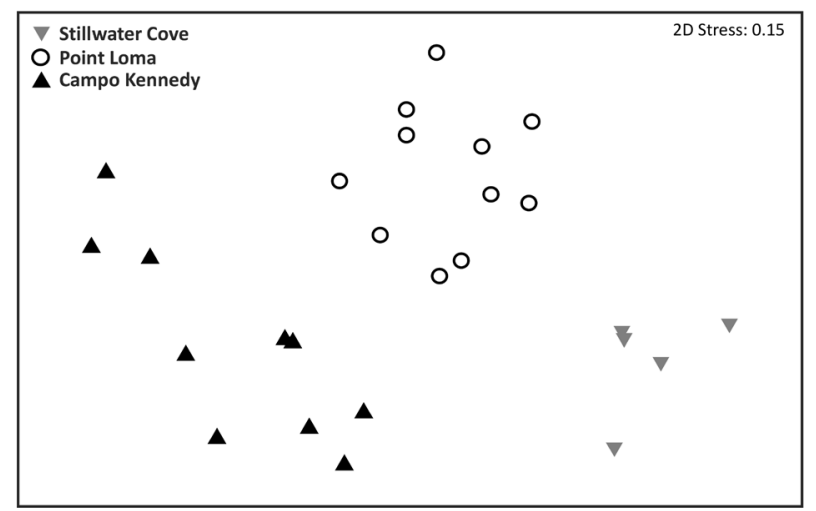

Fig. 3. Non-metric Multidimensional Scaling plot based on BrayCurtis similarities showing relative differences in macroalgal assemblages among the three study sites, Stillwater Cove, Point Loma, and Campo Kennedy. Data were fourth root transformed prior to analysis.
Kennedy, and lowest at Point Loma. BR was also greatest in Stillwater Cove, but was lowest at Campo Kennedy and intermediate at Point Loma. In contrast, during summer 2018, NBP and BR were both greatest in Point Loma, intermediate at Stillwater Cove and lowest at Campo Kennedy (Table 3, Fig. 4). These differences appeared driven by species-specific, mass-dependent rates of photosynthesis and respiration by the dominant macroalgae, which varied among the three sites and two sample periods (Table 4). Consequently, as with macroalgal diversity and biomass, estimates of NBP and BR and their drivers appeared to exhibit different temporal patterns within each site, and we therefore consider them at each site separately.

Stillwater Cove. During spring 2018, we observed the lowest overall macroalgal diversity in Stillwater Cove (Shannon Diversity Index, $\mathrm{H}=0.94$ ), but the highest overall modeled rates of NBP $\left(4,245.04 \pm 425.84 \mathrm{mg} \mathrm{O}_{2} \mathrm{~m}^{-2} \mathrm{~d}^{-1}\right.$, mean \pm standard error) and BR $\left(-1,478.56 \pm 138.26 \mathrm{mg} \mathrm{O}_{2}\right.$ 


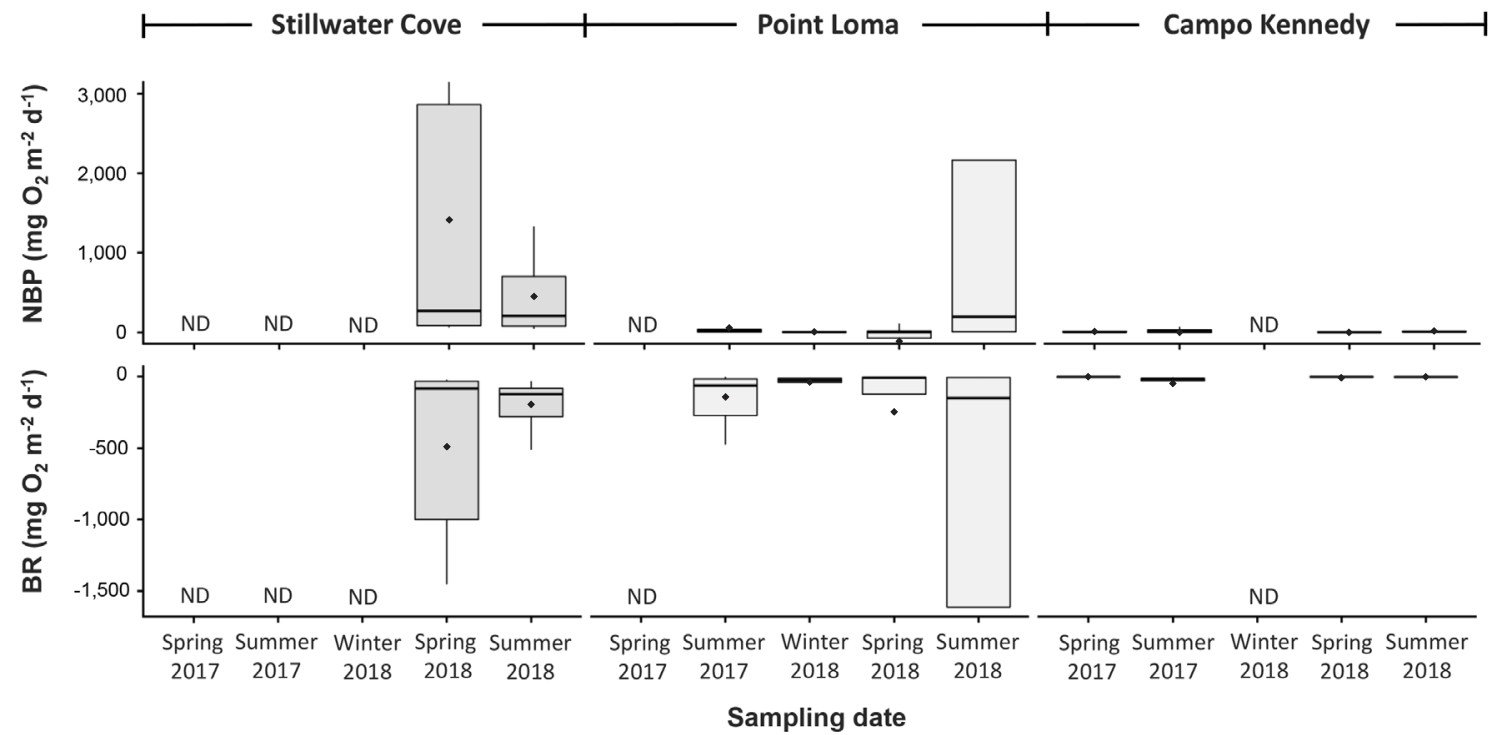

Fig. 4. Modeled estimates of net benthic production (NBP) and benthic respiration (BR) within the kelp forests at Stillwater Cove, Point Loma, and Campo Kennedy across all sampling periods using laboratory-based, species-specific rates of photosynthesis and respiration. Data are given as $\mathrm{mg} \mathrm{O}_{2}$ evolved $\mathrm{m}^{-2} \mathrm{~d}^{-1}$. Three replicate irradiance-dependent measurements of photosynthesis and / or respiration were made for each algal species whose combined abundances represented greater than $80 \%$ of the total macroalgal biomass at each site. The mass and irradiancedependent photosynthesis values for each species were modeled with in situ measurements of PAR and each species' abundance using a power function to estimate the amount of production lost due to deforestation. Diamonds represent the mean, black bars represent the median. The $y$-axis was constrained to provide the clearest resolution of the model. Differences in sampling frequency were due to logistical constraints, ND indicates no data.

$\mathrm{m}^{-2} \mathrm{~d}^{-1}$ ) (Tables 1 \& 3, Fig. 4). At this time, the understory kelp Dictyonerum californicum represented the largest contribution $(49 \%)$ to the similarity in assemblage characteristics at this site, followed by P. californica (34\%), and then Stephanocystis osmundacea (17\%) (SIMPER) (Table 5). However, P. californica was by far the most abundant species observed at this site, comprising approximately $61 \%$ of the total macroalgal biomass (Table 1, Fig. 2), and exhibited the highest individual rates of photosynthesis, producing $2.05 \mathrm{mg} \mathrm{O}_{2}$ g-thallus $^{-1} \mathrm{~d}^{-1}$. When scaled by its high biomass, our model suggests that $P$. californica contributed 3,905.84 $\pm 224.94 \mathrm{mg} \mathrm{O}_{2} \mathrm{~m}^{-2} \mathrm{~d}^{-1}$, which accounted for approximately $92 \%$ of the total estimated benthic productivity at this site (Table 4). In contrast, although the SIMPER analyses identified D. californiucm and S. osumndacea as being important to defining the macroalgal community at Stillwater Cove (Table 5), they comprised far less of the biomass and contributed only a small amount to the estimated NBP. Specifically, D. californicum made up only $21 \%$ of the biomass, and had much

Table 3. Modeled net benthic production (NBP) and benthic respiration (BR) at Stillwater Cove, Point Loma, and Campo Kennedy using laboratory-based, species-specific rates of photosynthesis and respiration

\begin{tabular}{|c|c|c|c|}
\hline Site & Season / Year & NBP & BR \\
\hline \multirow[t]{2}{*}{ Stillwater Cove } & Spring, 2018 & $4,245.04 \pm 425.84$ & $-1,478.56 \pm 138.26$ \\
\hline & Summer, 2018 & $1,290.76 \pm 320.43$ & $-601.07 \pm 159.62$ \\
\hline \multirow[t]{4}{*}{ Point Loma } & Summer, 2017 & $419.91 \pm 49.27$ & $-838.82 \pm 123.49$ \\
\hline & Winter, 2018 & $19.98 \pm 6.14$ & $-131.56 \pm 49.36$ \\
\hline & Spring, 2018 & $-517.06 \pm 256.98$ & $-1,120.87 \pm 344.85$ \\
\hline & Summer, 2018 & $13,978.20 \pm 6,244.24$ & $-10,411.80 \pm 4,653.01$ \\
\hline \multirow[t]{4}{*}{ Campo Kennedy } & Spring, 2017 & $14.77 \pm 10.16$ & $-0.11 \pm 0.09$ \\
\hline & Summer, 2017 & $-53.96 \pm 101.18$ & $-120.83 \pm 83.91$ \\
\hline & Spring, 2018 & $-57.72 \pm 20.85$ & $-77.27 \pm 25.83$ \\
\hline & Summer, 2018 & $25.62 \pm 11.85$ & $-5.94 \pm 4.94$ \\
\hline
\end{tabular}

Estimates are scaled to $1 \mathrm{~m}^{2}$ per day across all sampling periods. The mass and irradiance-dependent photosynthesis values for each species were modeled with in situ measurements of PAR and each species' abundance using a power function to estimate the amount of production lost due to deforestation. Data denote mean \pm standard error for each metric as $\mathrm{mg} \mathrm{O}_{2} \mathrm{~m}^{-2} \mathrm{~d}^{-1}$. Negative values denote net respiration. 
Table 4. Species-specific rates of production (net), based on incubations for all species sampled across sites and sampling dates

\begin{tabular}{|c|c|c|c|c|}
\hline Site & Season / Year & Species & Net production & Contribution (\%) \\
\hline \multirow[t]{6}{*}{ Stillwater Cove } & Spring, 2018 & Pterygophora californica & $3,905.84 \pm 224.94$ & 92.01 \\
\hline & Spring, 2018 & Dictyoneurum californicum & $245.46 \pm 171.49$ & 5.78 \\
\hline & Spring, 2018 & Stephanocystis osmundacea & $93.74 \pm 29.41$ & 2.21 \\
\hline & Summer, 2018 & Pterygophora californica & $1,088.46 \pm 242.65$ & 84.33 \\
\hline & Summer, 2018 & Dictyoneurum californicum & $157.46 \pm 62.83$ & 12.2 \\
\hline & Summer, 2018 & Cryptopleura ruprechtiana & $44.84 \pm 14.95$ & 3.47 \\
\hline \multirow[t]{19}{*}{ Point Loma } & Summer, 2017 & Botryocladia pseudodichotoma & $1.81 \pm 0.22$ & 0.43 \\
\hline & Summer, 2017 & Laminaria farlowii & $27.88 \pm 9.06$ & 6.64 \\
\hline & Summer, 2017 & Gelidium spp. & $-58.8 \pm 19.6$ & -14 \\
\hline & Summer, 2017 & Ecklonia arborea & $407.68 \pm 0$ & 97.09 \\
\hline & Summer, 2017 & Stephanocystis osmundacea & $41.35 \pm 20.38$ & 9.85 \\
\hline & Winter, 2018 & Stephanocystis osmundacea & $10.4 \pm 0.8$ & 52.06 \\
\hline & Winter, 2018 & Botryocladia pseudodichotoma & $5.54 \pm 1.85$ & 27.75 \\
\hline & Winter, 2018 & Laminaria farlowii & $3.01 \pm 0.99$ & 15.08 \\
\hline & Winter, 2018 & Prionitis linearis & $3.5 \pm 1.17$ & 17.51 \\
\hline & Winter, 2018 & Pterygophora californica & $-2.48 \pm 1.33$ & -12.4 \\
\hline & Spring, 2018 & Stephanocystis osmundacea & $63.59 \pm 46.34$ & -12.3 \\
\hline & Spring, 2018 & Botryocladia pseudodichotoma & $3.57 \pm 1.19$ & -0.69 \\
\hline & Spring, 2018 & Laminaria farlowii & $-570.1 \pm 153.97$ & 110.26 \\
\hline & Spring, 2018 & Prionitis linearis & $23.95 \pm 22.27$ & -4.63 \\
\hline & Spring, 2018 & Pterygophora californica & $-38.07 \pm 33.21$ & 7.36 \\
\hline & Summer, 2018 & Stephanocystis osmundacea & $7.41 \pm 0.39$ & 0.05 \\
\hline & Summer, 2018 & Laminaria farlowii & $13,520.5 \pm 5,921.03$ & 96.73 \\
\hline & Summer, 2018 & Prionitis linearis & $448.06 \pm 322.07$ & 3.21 \\
\hline & Summer, 2018 & Pterygophora californica & $2.24 \pm 0.75$ & 0.02 \\
\hline \multirow[t]{10}{*}{ Campo Kennedy } & Spring, 2017 & Botryocladia pseudodichotoma & $2.57 \pm 0.86$ & 17.37 \\
\hline & Spring, 2017 & Zonaria farlowii & $12.21 \pm 9.31$ & 82.63 \\
\hline & Summer, 2017 & Zonaria farlowii & $42.77 \pm 16.46$ & -79.27 \\
\hline & Summer, 2017 & Gelidium spp. & $-117.97 \pm 78.64$ & 218.63 \\
\hline & Summer, 2017 & Stephanocystis osmundacea & $21.23 \pm 6.07$ & -39.35 \\
\hline & Spring, 2018 & Gelidium spp. & $-61.45 \pm 20.48$ & 106.48 \\
\hline & Spring, 2018 & Botryocladia pseudodichotoma & $0.13 \pm 0.08$ & -0.23 \\
\hline & Spring, 2018 & Sargassum horneri & $3.61 \pm 0.28$ & -6.25 \\
\hline & Summer, 2018 & Prionitis linearis & $17.78 \pm 11.85$ & 69.39 \\
\hline & Summer, 2018 & Zonaria farlowii & $7.84 \pm 0$ & 30.61 \\
\hline
\end{tabular}

Species-specific rates of productivity are scaled to $1 \mathrm{~m}^{2}$, light levels were integrated across one $24 \mathrm{~h}$ cycle for each date sampled. Net production data denote mean \pm standard error as $\mathrm{mg} \mathrm{O}_{2} \mathrm{~m}^{-2} \mathrm{~d}^{-1}$. Negative values denote net respiration.

Table 5. Results of SIMPER analysis examining the individual (contribution, \%) and cumulative (\%) contributions of various taxa to the overall similarities in algal biomass within each site across all sampling periods for Stillwater Cove, Point Loma, and Campo Kennedy

\begin{tabular}{llcrcc}
\hline Site / Average similarity & \multicolumn{1}{c}{ Species } & Abundance & Similarity & $\begin{array}{c}\text { Contribution } \\
\text { (\%) }\end{array}$ & $\begin{array}{c}\text { Cumulative } \\
\text { contribution (\%) }\end{array}$ \\
\hline Stillwater Cove: 59.48 & Dictyonerum californicum & 3.91 & $29.39 \pm 5.47$ & 49.41 & 49.41 \\
& Pterygophora californica & 4.33 & $20.13 \pm 0.87$ & 33.84 & 83.25 \\
& Stephanocystis osmundacea & 2.46 & $9.97 \pm 0.78$ & 16.75 & 100 \\
Point Loma: 50.45 & Laminaria farlowii & 4.62 & $22.79 \pm 2.76$ & 45.17 & 45.17 \\
& Stephanocystis osmundacea & 2.58 & $7.98 \pm 1.13$ & 15.81 & 60.98 \\
& Leptocladia binghamiae & 2.25 & $7.04 \pm 0.85$ & 13.94 & 74.93 \\
& Pterygophora californica & 2.14 & $6.29 \pm 0.72$ & 12.46 & 87.38 \\
Campo Kennedy: 64.49 & Calliarthron spp. & 1.12 & $2.69 \pm 0.62$ & 5.33 & 92.71 \\
& Gelidium spp. & 2 & $15.35 \pm 0.83$ & 23.79 & 23.79 \\
& Prionitis linearis & 2.38 & $8.81 \pm 0.67$ & 13.65 & 37.45 \\
\hline
\end{tabular}

Prior to analysis, data were fourth root transformed to down weight the influence of overly abundant species. Abundance denotes as average. Similarity denotes as mean \pm standard deviation within each site. 
lower rates of photosynthesis, contributing approximately $0.34 \mathrm{mg} \mathrm{O}_{2}$ g-thallus ${ }^{-1} \mathrm{~d}^{-1}$. Consequently, when scaled by its biomass, our model suggests $D$. californicum contributed $245.46 \pm 171.49 \mathrm{mg} \mathrm{O}_{2} \mathrm{~m}^{-2} \mathrm{~d}^{-1}$, which accounted for approximately $6 \%$ of the estimated NBP at this site (Table 4). Likewise, S. osumndacea comprised $15 \%$ of the biomass and had even lower rates of photosynthesis, contributing $18.34 \mathrm{mg} \mathrm{O}_{2}$ g-thallus ${ }^{-1} \mathrm{~d}^{-1}$. As a result, our model estimates that $S$. osumndacea contributed only $93.74 \pm 29.41 \mathrm{mg} \mathrm{O}_{2} \mathrm{~m}^{-2} \mathrm{~d}^{-1}$, which is only about $2 \%$ of the estimated NBP at this site. During summer 2018, in contrast, we observed the highest macroalgal diversity at Stillwater Cove $(\mathrm{H}=1.04)$ but only intermediate rates of modeled NBP $\left(1,290.76 \pm 320.43 \mathrm{mg} \mathrm{O}_{2} \mathrm{~m}^{-2} \mathrm{~d}^{-1}\right)$ and BR $\left(-601.07 \pm 159.62 \mathrm{mg} \mathrm{O}_{2} \mathrm{~m}^{-2} \mathrm{~d}^{-1}\right.$ ) (Tables 1 \& 3, Figs 2 \& 4). As with spring 2018 , P. californica was again the most abundant species, comprising approximately $60 \%$ of the biomass and exhibiting the highest rates of photosynthesis, although these were considerably lower than in spring $2018\left(0.69 \mathrm{mg} \mathrm{O}_{2}\right.$ g-thallus $\left.{ }^{-1} \mathrm{~d}^{-1}\right)$. Thus, when scaled by its biomass, our model suggests that $P$. californica contributed $1,088.46 \pm 242.65 \mathrm{mg} \mathrm{O}_{2} \mathrm{~m}^{-2} \mathrm{~d}^{-1}$, which accounted for the largest amount (84\%) of the estimated NBP at this site (Table 4). D. californicum and the red alga Cryptopleura ruprechtiana, which were both observed in low abundances (Table 1, Fig. 2) and exhibited lower rates of photosynthesis, together contributed the remaining 16\% to modeled benthic productivity (Table 4 ).

Point Loma. During spring 2018, we observed the highest overall macroalgal diversity in Point Loma $(\mathrm{H}=$ 1.42) but the lowest modeled rates NBP $(-517.106 \pm 256.98$ $\left.\mathrm{mg} \mathrm{O}_{2} \mathrm{~m}^{-2} \mathrm{~d}^{-1}\right)$ and intermediate levels of BR $(-1,120.87 \pm$ $344.85 \mathrm{mg} \mathrm{O}_{2} \mathrm{~m}^{-2} \mathrm{~d}^{-1}$ ) (Tables 1 \& 3, Figs 2 \& 4). In fact, our model estimates that the macroalgal community exhibited negative net productivity (i.e., net respiration) during this period. This macroalgal community was composed of a diverse mix of brown and red algae, with Laminaria farlowii representing the largest contribution (45\%) to the similarity in assemblage characteristics at this site, followed by S. osumndacea (16\%), Leptocladia binghamiae (14\%), P. californica (12\%), and coralline algae Calliarthron spp. (5\%) (SIMPER) (Table 5). L. farlowii was the most abundant species, comprising approximately $49 \%$ of the total macroalgal biomass, while P. californica was the second most abundant species, comprising approximately $25 \%$ of the biomass at this site (Table 1, Fig. 2). Both L. farlowii and P.californica exhibited net respiration (-0.42 and $-0.05 \mathrm{mg} \mathrm{O}_{2}$ g-thallus ${ }^{-1} \mathrm{~d}^{-1}$, respectively), and when scaled by their biomasses, our model suggests that L. farlowii contributed $-570.10 \pm 153.97 \mathrm{mg} \mathrm{O}_{2} \mathrm{~m}^{-2} \mathrm{~d}^{-1}$ and
P. californica contributed $-38.07 \pm 33.21 \mathrm{mg} \mathrm{O}_{2} \mathrm{~m}^{-2} \mathrm{~d}^{-1}$ to benthic productivity, which were approximately $82 \%$ and $5 \%$ of the modeled NBP at this site, respectively (Table 4). The remaining species comprised less than $25 \%$ of the macroalgal biomass and exhibited low rates of productivity (Tables $1 \& 4$, Fig. 2). Thus, our model estimates that when combined, they contributed an estimated $91.11 \mathrm{O}_{2}$ $\mathrm{m}^{-2} \mathrm{~d}^{-1}$, which was approximately $13 \%$ of the NBP at this site. Together, this indicated that the combined high biomasses and net respirations of $L$. farlowii and P. californica were the likely causes of the macroalgal community at Point Loma being estimated as net respiration driven during this period (Tables 3 \& 4, Fig. 4). In contrast, during summer 2018, we observed low macroalgal diversity at Point Loma, which was similar to that at Campo Kennedy $(\mathrm{H}=0.89$ ) (Table 1$)$, but the highest rates of NBP $\left(13,978.20 \pm 6,244.24 \mathrm{mg} \mathrm{O}_{2} \mathrm{~m}^{-2} \mathrm{~d}^{-1}\right)$ and BR $(-10,411.80$ $\left.\pm 4,653.01 \mathrm{mg} \mathrm{O}_{2} \mathrm{~m}^{-2} \mathrm{~d}^{-1}\right)$. L. farlowii was again the most abundant species, comprising approximately $72 \%$ of the macroalgal biomass, and exhibited some of the highest rates of photosynthesis observed during this study (4.98 mg $_{2}$ g-thallus ${ }^{-1} \mathrm{~d}^{-1}$ ). When scaled by its high biomass, our model suggests L. farlowii contributed 13,520.50 \pm $5,921.03 \mathrm{mg} \mathrm{O}_{2} \mathrm{~m}^{-2} \mathrm{~d}^{-1}$, which was approximately $97 \%$ of the estimated NBP at this site. Interestingly, P. californica and S. osumndacea both occurred in very low abundances in our samples (Table 1, Fig. 2) and together were estimated to have contributed less than $1 \%$ to the modeled NBP (Table 4). Due to our inability to sample Stillwater Cove during other sampling periods, we do not compare modeled NBP and BR among the sites here. However, patterns of macroalgal diversity, species abundances, their photosynthetic rates and contribution to benthic productivity, and modeled NBP and BR for Point Loma during the additional sampling periods can be seen in Tables $1,3 \& 4$, and Figs $2 \& 4$.

Campo Kennedy. During spring 2018, we observed intermediate macroalgal diversity $(\mathrm{H}=1.10)$ and relatively low modeled rates of NBP $\left(-57.72 \pm 20.85 \mathrm{mg} \mathrm{O}_{2} \mathrm{~m}^{-2} \mathrm{~d}^{-1}\right)$ at Campo Kennedy, and the lowest rates of modeled BR $\left(-120.83 \pm 83.91 \mathrm{mg} \mathrm{O}_{2} \mathrm{~m}^{-2} \mathrm{~d}^{-1}\right)$ (Tables 1 \& 3, Figs 2 \& 4). As with Stillwater Cove, our model suggests that the benthic macroalgal communities at Campo Kennedy exhibited net respiration during this period. However, unlike Stillwater Cove and Point Loma, which were dominated by large kelps, the benthic macroalgal assemblages at Campo Kennedy were comprised of several species of smaller red and brown algae. In particular, the red algae Gelidium spp. and Prionitis linearis represented the largest contributions ( $24 \%$ and $14 \%$, respectively) to the simi- 
larities in assemblage characteristics at this site, followed by the brown algae Zonaria farlowii (13\%), S. osmundacea (12\%), and Sargassum horneri (11\%), and then by the red algae Calliarthron spp. (9\%) and Botryocladia pseudodichotoma (6\%) (SIMPER) (Table 5). Gelidium spp. was the most abundant species in spring 2018, comprising approximately $78 \%$ of the biomass, and exhibited net respiration $\left(-0.13 \mathrm{mg} \mathrm{O}_{2}\right.$ g-thallus $\left.{ }^{-1} \mathrm{~d}^{-1}\right)$. When scaled by its biomass, our model suggests that Gelidium spp. contributed $-61.45 \pm 20.48 \mathrm{mg} \mathrm{O}_{2} \mathrm{~m}^{-2} \mathrm{~d}^{-1}$ to benthic productivity, which was approximately $94 \%$ of the NBP at this site (Table 4). S. horneri was the second most abundant species, comprising approximately $11 \%$ of the biomass, followed by B. pseudodichotoma, which comprised approximately $7 \%$ of the biomass during this period. However, S. horneri and B. pseudodichotoma both exhibited low rates of net photosynthesis $\left(0.06 \mathrm{mg} \mathrm{O}_{2}\right.$ g-thallus ${ }^{-1} \mathrm{~d}^{-1}$ and $<0.01 \mathrm{mg} \mathrm{O}_{2}$ g-thallus ${ }^{-1} \mathrm{~d}^{-1}$, respectively). When scaled by their biomasses, our model estimates that $S$. horneri contributed $3.62 \pm 0.28 \mathrm{mg} \mathrm{O}_{2} \mathrm{~m}^{-2} \mathrm{~d}^{-1}$ and B. pseudodichotoma contributed $0.13 \pm 0.008 \mathrm{mg} \mathrm{O}_{2}$ g-thallus ${ }^{-1} \mathrm{~d}^{-1}$ to the benthic productivity, which were approximately $6 \%$ and $<1 \%$ of the estimated NBP at this site, respectively (Table 4). Together, this indicated that the high biomass and net respiration of Gelidium spp. were the likely causes of the macroalgal community at Campo Kennedy being estimated as net respiration driven during this period (Table 4, Fig. 4). Finally, during summer 2018, we observed low macroalgal diversity that was similar to that observed in Point Loma ( $\mathrm{H}=0.88$ ) (Table 1), and the lowest modeled rates of NBP $\left(25.62 \pm 11.85 \mathrm{mg} \mathrm{O}_{2} \mathrm{~m}^{-2} \mathrm{~d}^{-1}\right)$ and BR (-5.94 $\pm 4.94 \mathrm{mg} \mathrm{O}_{2} \mathrm{~m}^{-2} \mathrm{~d}^{-1}$ ) (Tables $1 \& 3$, Figs $2 \& 4$ ). Unlike in spring 2018, the most abundant macroalgae at Campo Kennedy during summer 2018 were P. linearis, which comprised approximately $56 \%$ of the total biomass, and by Gelidium spp., which comprised approximately $41 \%$ of the biomass. P. linearis exhibited low rates of photosynthesis $\left(0.059 \mathrm{mg} \mathrm{O}_{2}\right.$ g-thallus $\left.{ }^{-1} \mathrm{~d}^{-1}\right)$. Unfortunately, the Gelidium spp. samples did not survive until they could be analyzed in the laboratory, and thus we did not obtain photosynthesis or respiration measurements for them in summer 2018. Consequently, our model only includes the two other dominant species, P. linearis and $Z$. farlowii. When scaled by its biomasses, $P$. linearis contributed $17.78 \pm 11.85 \mathrm{mg} \mathrm{O}_{2} \mathrm{~m}^{-2} \mathrm{~d}^{-1}$, which was approximately $70 \%$ of the modeled remaining NBP at this site (Table 4). In contrast, $Z$. farlowii occurred in low abundances, comprising approximately $2 \%$ of the biomass at Campo Kennedy, but it exhibited high rates pf photosynthesis $\left(0.08 \mathrm{mg} \mathrm{O}_{2}\right.$ g-thallus $\left.{ }^{-1} \mathrm{~d}^{-1}\right)$, which resulted in it contribut- ing $7.84 \mathrm{mg} \mathrm{O}_{2} \mathrm{~m}^{-2} \mathrm{~d}^{-1}$, which was approximately $30 \%$ of the modeled remaining NBP at this site (Table 4). However, this was based on a single replicate, thus we advise caution when comparing Campo Kennedy to the other sites. However, these species are included in spring and summer 2017; patterns of macroalgal diversity, species abundances, their photosynthetic rates and contribution to benthic productivity, and modeled NBP and BR for Campo Kennedy during these two additional sampling periods can be seen in Tables 1,3 \& 4, and Figs 2 \& 4 .

\section{DISCUSSION}

We modeled the amount of photosynthesis and respiration that the dominant benthic macroalgae inhabiting Macrocystis forests contribute to net benthic primary production at three sites spanning several hundred kilometers of latitude along the California, USA and Baja California, MEX coasts. Although our model does not address compensatory production by crustose coralline algae or benthic and / or planktonic microalgae (e.g., Miller et al. 2012), our overarching goal was to estimate how the loss of these species' due to deforestation affects patterns of benthic production and respiration at each of these sites. To do this, we measured biomass-specific rates of net photosynthesis and respiration for the most abundant macroalgae (those comprising $>80 \%$ of the total biomass) at each site using a range of naturally occurring irradiances in the laboratory. We paired these mass-specific, irradiance-dependent measurements with field-based estimates of each species' biomass and in situ irradiances at each site to model their contribution to benthic productivity within these forests. Overall, our model estimates that the dominant macroalgae in these forests contribute approximately $15-4,300 \mathrm{mg} \mathrm{C} \mathrm{m}^{-2} \mathrm{~d}^{-1}$ to net benthic primary production, but that this was variable among the study sites and seasons due to differences in the abundances and metabolisms of a few dominant species. Thus, our model suggests that the loss of these macroalgae may result in a significant decline in net benthic productivity.

Similar to Reed et al. (2011) who found that Macrocystis biomass was the best predictor of annual productivity within the forest it creates, our model suggests that the biomass of the most abundant benthic macroalgae was an important driver of benthic primary production on these rocky reefs. For example, during spring 2018, we observed the lowest macroalgal diversity but the highest biomass in Stillwater Cove, which also had the high- 
est rates of modeled benthic productivity. In contrast, we observed the highest macroalgal diversity and intermediate biomass, but the lowest rates of modeled benthic productivity in Point Loma. We observed intermediate macroalgal diversity, the lowest biomass, and intermediate rates of modeled benthic productivity at Campo Kennedy. Moreover, the benthic assemblages at Point Loma and Campo Kennedy were both estimated to be net respiration driven during this period, with Point Loma being strongly respiration driven. These patterns appeared due to the species-specific, mass-dependent rates of productivity and respiration by the dominant taxa at each site. In particular, the most abundant taxa at Stillwater cove was Pterygophora californica, which made up approximately $61 \%$ of the macroalgal biomass and exhibited the highest rates of productivity by any species observed during this period. In contrast, approximately $57 \%$ of the macroalgal biomass in Point Loma was comprised of a combination of Laminaria farlowii and P. californica, both of which exhibited high rates of respiration. The most abundant taxon at Campo Kennedy was Gelidium spp., which made up approximately $78 \%$ of the macroalgal biomass but was in relatively low abundance compared to macroalgae at the other sites and exhibited moderate rates of respiration. These patterns, however, changed during summer 2018, when our model suggested all three sites exhibited net benthic productivity. Here, Point Loma exhibited low macroalgal diversity but the highest overall macroalgal biomass and the greatest modeled benthic productivity. Stillwater Cove exhibited the highest species diversity, but it had intermediate levels of both macroalgal biomass and modeled benthic productivity. Conversely, Campo Kennedy had similarly low macroalgal diversity to Point Loma, and it exhibited the lowest overall macroalgal biomass and modeled benthic productivity. As with spring 2018, these patterns appeared to be driven by species-specific rates of photosynthesis and respiration combined with the biomass of the dominant taxa at each site. Specifically, Point Loma was dominated by $L$. farlowii, which made up approximately $72 \%$ of the macroalgal biomass during this period and exhibited the highest rates of photosynthesis of any taxa observed during the study. Stillwater Cove was again unsurprisingly dominated by $P$. californica, which exhibited high rates of photosynthesis, although these rates and its biomass were not as great as for L. farlowii in Point Loma. Campo Kennedy was dominated by Gelidium spp. and Prionitis linearis, which together made up approximately $97 \%$ of the biomass at this site, but these two species occurred in relatively low abundances and exhibited low rates of photosynthesis relative to the other sites. Thus, our data suggest that modeled estimates of benthic productivity more closely follow species-specific, biomass-dependent rates of photosynthesis and respiration than macroalgal diversity. Further, our data highlight that photosynthesis and respiration by individual species can vary among sites and between seasons as seen for $L$. farlowii and $P$. californica, and thus they can contribute differentially to benthic productivity. In contrast to the kelp forests, there were little-to-no macroalgae present in any of the adjacent deforested habitats, except for Point Loma where only a few red algae were present throughout the course of this study (unpublished data). The only other visible autotrophs in these deforested areas were crustose coralline algae, which together with microalgae can elevate production following deforestation due to increased irradiances (Miller et al. 2012). However, measuring productivity by crustose coralline algae requires different approaches (e.g., Kim et al. 2020), and we were unable to include these in our model. Thus, while we recognize that compensatory production may make up for some of this lost production, we limit our inference to the lost contribution of fleshy macroalgae following deforestation.

That the dominant macroalgae at each site exhibited variable rates of primary production was not surprising, especially given numerous other studies have observed species-specific responses to changes in irradiance (e.g., Binzer et al. 2006, Middleboe et al. 2006, Reed et al. 2011, $\mathrm{Kim}$ et al. 2016). However, we are careful to point out here that we did not conduct traditional photosynthesis-irradiance measurements in this study, and therefore cannot make conclusions about photosynthetic parameters, such as photosynthetic efficiency under non-saturating irradiances $(\alpha)$, maximum rates of photosynthesis $\left(\mathrm{P}_{\max }\right)$, or saturation irradiances $\left(I_{k}\right)$. Rather, we sought to increase the number of measurements of photosynthesis under a range of irradiances that these algae likely experience at these sites (as measured in the field with PAR loggers), with the ultimate goal of modeling how each species contributes to benthic primary productivity. Here, $P$. californica exhibited the highest mass-specific rates of photosynthesis and the greatest biomass at Stillwater cove in both spring and summer 2018, and therefore was likely the primary driver of the high rates of benthic productivity at this site. L. farlowii exhibited the greatest biomass and the highest mass-specific rates of respiration (in spring 2018) and photosynthesis (in summer 2018) at Point Loma, and therefore was likely the primary driver of BR and productivity, respectively. In contrast, Campo Kennedy lacked large benthic stipitate kelps and 
was instead dominated by low biomasses of red algae such as Gelidium spp. and P. linearis, which exhibited low mass-specific rates of respiration and photosynthesis, and therefore were likely the primary drivers of the low rates of BR and productivity at this site in spring and summer 2018, respectively. Thus, some macroalgae are more productive than others due to differences in both their metabolism as well as their biomass (Middleboe et al. 2006). In addition, although we did not include these in our model, other abiotic factors such as temperature and nutrient availability, which vary geographically and seasonally (Edwards and Estes 2006) may impact the abundance and metabolism of macroalgae differently (e.g., Kopczack et al. 1991, Matson and Edwards 2007, Brown et al. 2014). Thus, quantifying how these environmental factors vary among sites and seasons, and measuring how this variability affects macroalgal metabolism can improve our understanding of the root causes of spatiotemporal differences in benthic macroalgal production on rocky reefs. However, our model suggests a clear loss of benthic production and respiration following kelp forest deforestation. Therefore, while Macrocystis may be the largest and most productive macroalga on these rocky reefs, it is important to consider production associated with the understory assemblage (Miller et al. 2011). Indeed, our model suggests that the understory algae within these kelp forests contribute 0.15 to $4.3 \mathrm{~g} \mathrm{C} \mathrm{m}^{-2} \mathrm{~d}^{-1}$ to net benthic production, which is similar to the estimates made by Miller et al. (2012). This is also within the estimated $500 \mathrm{~g} \mathrm{C} \mathrm{m}^{-2} \mathrm{y}^{1}$ of carbon sequestration made by Reed and Brzezinski (2009), though our model suggest that this contribution is highly variable among sites and seasons. In a time of unprecedented ecological change to these marine forests, understanding alterations to community assemblages is pivotal to a deeper understanding of the deleterious impacts of their loss on temperate rocky reefs.

\section{ACKNOWLEDGEMENTS}

Campo Kennedy is managed by the Emmanuel Cantu Fishing Cooperative (Buzos y Pescadores de la Baja California), who's assistance was instrumental in the completion of this study. This study could not have been completed without the help of the San Diego BEERPIGs, Dr. Ju-Hyoung Kim, Dr. Luke Miller, UABC and MexCal, Moss Landing Marine Labs, and UC Santa Cruz. We personally want to thank E. Ricketts, T. McHugh, P. Saldaña, Dr. R. Beas, D. Diez, P. Webster, S. Gabara, and B. Beckley for their support, guidance, and hospitality. Funding was provided, in part, by the Explorers Club and the Meyers Family Trust. All necessary permits were obtained by CDFW, MBNMS, and APHIS for the described field study. This is contribution No. 71 to the Coastal and Marine Institute Laboratory, San Diego State University.

\section{REFERENCES}

Anderson, M. J. 2017. Permutational Multivariate Analyses of Variance (PERMANOVA). Wiley StatsRef: Statistics Reference Online. Available from: https://doi. org/10.1002/9781118445112.stat07841. Accessed Aug 19, 2020.

Barrón, C. \& Duarte, C. M. 2015. Dissolved organic carbon pools and export from the coastal ocean. Global Biogeochem. Cycles 29:1725-1738.

Bell, T. W., Cavanaugh, K. C., Reed, D. C. \& Siegel, D. A. 2015. Geographical variability in the controls of giant kelp biomass dynamics. J. Biogeogr. 42:2010-2021.

Binzer, T., Sand-Jensen, K. \& Middelboe, A. -L. 2006. Community photosynthesis of aquatic macrophytes. Limnol. Oceanogr. 51:2722-2733.

Bodkin, J. L. 1988. Effects of kelp forest removal on associated fish assemblages in central California. J. Exp. Mar. Biol. Ecol. 117:227-238.

Bradley, R. A. \& Bradley, D. W. 1993. Wintering shorebirds increase after kelp (Macrocystis) recovery. Condor 95:372376.

Brown, M. B., Edwards, M. S. \& Kim, K. Y. 2014. Effects of climate change on the physiology of giant kelp, Macrocystis pyrifera, and grazing by purple urchin, Strongylocentrotus purpuratus. Algae 29:203-215.

Carney, L. T., Bohonak, A. J., Edwards, M. S. \& Alberto, F. 2013. Genetic and experimental evidence for a mixedage, mixed-origin bank of kelp microscopic stages in southern California. Ecology 94:1955-1965.

Carr, M. H. 1994. Effects of macroalgal dynamics on recruitment of a temperate reef fish. Ecology 75:1320-1333.

Clark, R. P., Edwards, M. S. \& Foster, M. S. 2004. Effects of shade from multiple kelp canopies on an understory algal assemblage. Mar. Ecol. Prog. Ser. 267:107-119.

Connell, S. D. \& Russell, B. D. 2010. The direct effects of increasing $\mathrm{CO}_{2}$ and temperature on non-calcifying organisms: increasing the potential for phase shifts in kelp forests. Proc. R. Soc. B Biol. Sci. 277:1409-1415.

Dayton, P. K., Currie, V., Gerrodette, T., Keller, B. D., Rosenthal, R. \& Van Tresca, D. 1984. Patch dynamics and stability of some California kelp communities. Ecol. 
Monogr. 54:253-289.

Dayton, P. K., Tegner, M. J., Edwards, P. B. \& Riser, K. L. 1998. Sliding baselines, ghosts, and reduced expectations in kelp forest communities. Ecol. Appl. 8:309-322.

Duarte, C. M. \& Agustí, S. 1998. The $\mathrm{CO}_{2}$ balance of unproductive aquatic ecosystems. Science 281:234-236.

Duarte, C. M. \& Cebrián, J. 1996. The fate of marine autotrophic production. Limnol. Oceanogr. 41:1758-1766.

Ebeling, A. W., Laur, D. R. \& Rowley, R. J. 1985. Severe storm disturbances and reversal of community structure in a southern California kelp forest. Mar. Biol. 84:287-294.

Edwards, M., Konar, B., Kim, J. -H., Gabara, S., Sullaway, G., McHugh, T., Spector, M. \& Small, S. 2020. Marine deforestation leads to widespread loss of ecosystem function. PLoS ONE 15:e0226173.

Edwards, M. S. 1998. Effects of long-term kelp canopy exclusion on the abundance of the annual alga Desmarestia ligulata (Light F). J. Exp. Mar. Biol. Ecol. 228:309-326.

Edwards, M. S. 2001. Scale-dependent patterns of community regulation in giant kelp forests. Ph.D. dissertation, University of California, Santa Cruz, CA, 140 pp.

Edwards, M. S. 2004. Estimating scale-dependency in disturbance impacts: El Niños and giant kelp forests in the northeast Pacific. Oecologia 138:436-447.

Edwards, M. S. 2019. Comparing the impacts of four ENSO events on giant kelp (Macrocystis pyrifera) in the northeast Pacific Ocean. Algae 34:141-151.

Edwards, M. S. \& Estes, J. A. 2006. Catastrophe, recovery and range limitation in NE Pacific kelp forests: a large-scale perspective. Mar. Ecol. Prog. Ser. 320:79-87.

Edwards, M. S. \& Hernandez-Carmona, G. 2005. Delayed recovery of giant kelp near its southern range limit in the North Pacific following El Niño. Mar. Biol. 147:273-279.

Estes, J. A., Tinker, M. T., Williams, T. M. \& Doak, D. F. 1998. Killer whale predation on sea otters linking oceanic and nearshore ecosystems. Science 282:473-476.

Frieder, C. A., Nam, S. H., Martz, T. R. \& Levin, L. A. 2012. High temporal and spatial variability of dissolved oxygen and $\mathrm{pH}$ in a nearshore California kelp forest. Biogeosciences 9:3917-3930.

García-Robledo, E. \& Corzo, A. 2011. Effects of macroalgal blooms on carbon and nitrogen biogeochemical cycling in photoautotrophic sediments: an experimental mesocosm. Mar. Pollut. Bull. 62:1550-1556.

Graham, M. H. 2004. Effects of local deforestation on the diversity and structure of southern California giant kelp forest food webs. Ecosystems 7:341-357.

Graham, M. H. \& Edwards, M. S. 2001. Statistical significance versus fit: estimating the importance of individual factors in ecological analysis of variance. Oikos 93:505-513.
Hobday, A. J. 2000. Age of drifting Macrocystis pyrifera (L.) C. Agardh rafts in the Southern California Bight. J. Exp. Mar. Biol. Ecol. 253:97-114.

Holbrook, S. J., Carr, M. H., Schmitt, R. J. \& Coyer, J. A. 1990. Effect of giant kelp on local abundance of reef fishes: the importance of ontogenetic resource requirements. Bull. Mar. Sci. 47:104-114.

Hondolero, D. \& Edwards, M. S. 2017. Changes in ecosystem engineers: the effects of kelp forest type on currents and benthic assemblages in Kachemak Bay, Alaska. Mar. Biol. 164:81.

Jackson, G. A. 1984. Internal wave attenuation by coastal kelp stands. J. Phys. Oceanogr. 14:1300-1306.

Jackson, G. A. 1997. Currents in the high drag environment of a coastal kelp stand off California. Cont. Shelf Res. 17:1913-1928.

Kim, J. -H., Kang, E. J., Edwards, M. S., Lee, K., Jeong, H. J. \& Kim, K. Y. 2016. Species-specific responses of temperate macroalgae with different photosynthetic strategies to ocean acidification: a mesocosm study. Algae 31:243256.

Kim, J. -H., Kim, N., Moon, H., Lee, S., Jeong, S. Y., DiazPulido, G., Edwards, M. S., Kang, J. -H., Kang, E. J., Oh, H. -J., Hwang, J. -D. \& Kim, I. -N. 2020. Global warming offsets the ecophysiological stress of ocean acidification on temperate crustose coralline algae. Mar. Pollut. Bull. 157:111324.

Klinger, T., Chornesky, E. A., Whiteman, E. A., Chan, F, Largier, J. L. \& Wakefield, W. W. 2017. Using integrated, ecosystem-level management to address intensifying ocean acidification and hypoxia in the California Current large marine ecosystem. Elem. Sci. Anth. 5:16.

Konar, B., Edwards, M. S., Bland, A., Metzger, J., Ravelo, A., Traiger, S. \&Weitzman, B. 2017. A swath across the great divide: kelp forests across the Samalga Pass biogeographic break. Cont. Shelf Res. 143:78-88.

Kopczak, C. D., Zimmerman, R. C. \& Kremer, J. N. 1991. Variation in nitrogen physiology and growth among geographically isolated populations of the giant kelp, Macrocystis pyrifera (Phaeophyta). J. Phycol. 27:149-158.

Krumhansl, K. A., Okamoto, D. K., Rassweiler, A., Novak, M., Bolton, J. J., Cavanaugh, K. C., Connell, S. D., Johnson, C. R., Konar, B., Ling, S. D., Micheli, F., Norderhaug, K. M., Pérez-Matus, A., Sousa-Pinto, I., Reed, D. C., Salomon, A. K., Shears, N. T., Wernberg, T., Anderson, R. J., Barrett, N. S., Buschmann, A. H., Carr, M. H., Caselle, J. E., Derrien-Courtel, S., Edgar, G. J., Edwards, M., Estes, J. A., Goodwin, C., Kenner, M. C., Kushner, D. J., Moy, F. E., Nunn, J., Steneck, R. S., Vásquez, J., Watson, J., Witman, J. D. \& Byrnes, J. E. K. 2016. Global patterns of kelp forest 
change over the past half-century. Proc. Natl. Acad. Sci. U. S. A. 113:13785-13790.

Matson, P. G. \& Edwards, M. S. 2007. Effects of ocean temperature on the southern range limits of two understory kelps, Pterygophora californica and Eisenia arborea, at multiple life-stages. Mar. Biol. 151:1941-1949.

Metzger, J. R., Konar, B. \& Edwards, M. S. 2019. Assessing a macroalgal foundation species: community variation with shifting algal assemblages. Mar. Biol. 166:156.

Middelboe, A. L., Sand-Jensen, K. \& Binzer, T. 2006. Highly predictable photosynthetic production in natural macroalgal communities from incoming and absorbed light. Oecologia 150:464-476.

Miller, R. J., Harrer, S. \& Reed, D. C. 2012. Addition of species abundance and performance predicts community primary production of macroalgae. Oecologia 168:797-806.

Miller, R. J., Page, H. M. \& Reed, D. C. 2015. Trophic versus structural effects of a marine foundation species, giant kelp (Macrocystis pyrifera). Oecologia 179:1199-1209.

Miller, R. J., Reed, D. C. \& Brzezinski, M. A. 2011. Partitioning of primary production among giant kelp (Macrocystis pyrifera), understory macroalgae, and phytoplankton on a temperate reef. Limnol. Oceanogr. 56:119-132.

Minich, J. J., Morris, M. M., Brown, M., Doane, M., Edwards, M. S., Michael, T. P. \& Dinsdale, E. A. 2018. Elevated temperature drives kelp microbiome dysbiosis, while elevated carbon dioxide induces water microbiome disruption. PLoS ONE 13:e0192772.

Murie, K. A. \& Bourdeau, P. E. 2020. Fragmented kelp forest canopies retain their ability to alter local seawater chemistry. Sci. Rep. 10:11939.

Olivé, I., Silva, J., Costa, M. M. \& Santos, R. 2016. Estimating seagrass community metabolism using benthic chambers: the effect of incubation time. Estuaries and Coasts 39:138-144.

Pfister, C. A., Altabet, M. A. \& Weigel, B. L. 2019. Kelp beds and their local effects on seawater chemistry, productivity, and microbial communities. Ecology 100:e02798.

R Foundation for Statistical Computing. 2019. R: A language and environment for statistical computing. R Foundation for Statistical Computing, Vienna, Austria. Available from: http://www.R-project.org/. Accessed Aug 19, 2020.

Reed, D. C. \& Brzezinski, M. A. 2009. Kelp forests. In Laffoley, D. \& Grimsditch, G. (Eds.) The Management of Natural Coastal Carbon Sinks. International Union for Conserviation of Nature and Natural Resources, Gland, pp. 31-38.

Reed, D. C. \& Foster, M. S. 1984. The effects of canopy shadings on algal recruitment and growth in a giant kelp forest. Ecology 65:937-948.
Reed, D. C., Rassweiler, A. \& Arkema, K. K. 2008. Biomass rather than growth rate determines variation in net primary production by giant kelp. Ecology 89:2493-2505.

Reed, D. C., Rassweiler, A., Carr, M. H., Cavanaugh, K. C., Malone, D. P. \& Siegel, D. A. 2011. Wave disturbance overwhelms top-down and bottom-up control of primary production in California kelp forests. Ecology 92:2108-2116.

Rodgers, K. L., Rees, T. A. V. \& Shears, N. T. 2015. A novel system for measuring in situ rates of photosynthesis and respiration of kelp. Mar. Ecol. Prog. Ser. 528:101-115.

Schiel, D. R. \& Foster, M. S. 2015. The biology and ecology of giant kelp forests. University of California Press, Berkeley, 394 pp.

Schuurmans, R. M., van Alphen, P., Schuurmans, J. M., Matthijs, H. C. P. \& Hellingwerf, K. J. 2015. Comparison of the photosynthetic yield of cyanobacteria and green algae: different methods give different answers. PLoS ONE 10:e0139061.

Seymour, R. J., Tegner, M. J., Dayton, P. K. \& Parnell, P. E. 1989. Storm wave induced mortality of giant kelp, Macrocystis pyrifera, in southern California. Estuar. Coast. Shelf Sci. 28:277-292.

Shipe, R. F. \& Brzezinski, M. A. 2003. Siliceous plankton dominate primary and new productivity during the onset of El Niño conditions in the Santa Barbara Basin, California. J. Mar. Syst. 42:127-143.

Siddon, E. C., Siddon, C. E. \& Stekoll, M. S. 2008. Community level effects of Nereocystis luetkeana in southeastern Alaska. J. Exp. Mar. Biol. Ecol. 361:8-15.

Smith, S. V. \& Hollibaugh, J. T. 1993. Coastal metabolism and the oceanic organic carbon balance. Rev. Geophys. 31:75-89.

VanMeter, K. \& Edwards, M. S. 2013. The effects of mysid grazing on kelp zoospore survival and settlement. J. Phycol. 49:896-901.

Vásquez, J. A., Vega, J. A. \& Buschmann, A. H. 2006. Long term variability in the structure of kelp communities in northern Chile and the 1997-98 ENSO. In Anderson, R., Brodie, J., Onsøyen, E. \& Critchley, A. T. (Eds.) Eighteenth Int. Seaweed Symp. Springer, Dordrecht, pp. 279-293.

Ware, C., Dijkstra, J. A., Mello, K., Stevens, A. H., O’Brien, B. \& Ikedo, W. 2019. A novel three-dimensional analysis of functional architecture that describes the properties of macroalgae as a refuge. Mar. Ecol. Prog. Ser. 608:93-103.

Wernberg, T., Kendrick, G. A. \& Toohey, B. D. 2005. Modification of the physical environment by an Ecklonia radiata (Laminariales) canopy and implications for associated foliose algae. Aquat. Ecol. 39:419-430.

Wernberg, T., Thomsen, M. S., Tuya, F., Kendrick, G. A., Staehr, 
P. A. \& Toohey, B. D. 2010. Decreasing resilience of kelp beds along a latitudinal temperature gradient: potential implications for a warmer future. Ecol. Lett. 13:685-694. Williams, P. J. B. 1998. The balance of plankton respiration and photosynthesis in the open oceans. Nature 394:55-
57.

Wilmers, C. C., Estes, J. A., Edwards, M., Laidre, K. L. \& Konar, B. 2012. Do trophic cascades affect the storage and flux of atmospheric carbon? An analysis of sea otters and kelp forests. Front. Ecol. Environ. 10:409-415. 